\title{
SISTEM PENDETEKSI KEBISINGAN DAN VOICE ALERT SEBAGAI KONTROL KENYAMAN PASIEN RAWAT INAP BERBASIS MIKROKONTROLER
}

\author{
Yoyon Efendi, Rometdo Muzawi, Lusiana, Sularno \\ Program Studi Teknologi Informasi, STMIK Amik Riau \\ Program Studi Manajemen Informatika, STMIK Amik Riau \\ Program Studi Teknik Informatika, STMIK Amik Riau \\ Prodi Sistem Informasi Universitas Dharma Andalas, Indonesia \\ yoyonefendi@stmik-amik-riau.ac.id, rometdomuzawi@stmik-amik-riau.ac.id, \\ lusiana@stmik-amik-riau.ac.id, soelarno@unidha.ac.i
}

\begin{abstract}
Abstrak
Rumah Sakit seharusnya tidak ada kebisingan karena sebagai media pemulihan dari masalah kesehatan, tapi nyatanya beberapa ruangan dir Rumah Sakit sangat tinggi kebisingannya.Salah satunya pada ruang rawat inap mulai dari suara tenaga kesehatan dan pengunjung. Kebisingan ini akan menggangu tahap penyembuhan pasien sehingga berdampak kepada psikologis berupa kurang nyaman, konsentrasi dan mudah marah. Diperlukan sistem pendeteksi dan Voice Alert sebagai kontrol di Rumah Sakit. Sistem ini berbasis mikrokontroller dengan peralatan ATMega 8585, ISD 2560, Electric Condenser Micphone (ECM). Hasilnya akanmenghasilkan sistem dengan tampilan di LCD satuan Decibel (dB). Output nya berupa pesan suara (Voice Alert) berdasarkan batas nilai maksimal kebisingan.Sistem ini akan memberikan kenyaman pasien dan memudahkan petugas ruang rawat inap dalam mengontrol kondisi ruangan dan pasien.
\end{abstract}

Kata kunci:Pendeteksi Bising, Voice Alert, Rawat Inap, Mikrokontroller

\section{Abstract}

Hospitals should not have any noise because as a medium of recovery from health problems, but in fact some rooms at the Hospital are very high noise. One of them in the inpatient room starts from the sound of health workers and visitors. This noise will disrupt the patient's healing stage so that the psychological impact of discomfort, concentration and irritability. Detection system and Voice Alert are needed as a control at the Hospital. This system is based on a microcontroller with ATMega 8585, ISD 2560, Electric Condenser Micphone (ECM) equipment. The result will produce a system with a display on the LCD Decibel unit $(d B)$. The output is Voice Alert based on the maximum noise value. This system will provide patient comfort and facilitate inpatient staff in controlling the condition of the room and the patient.

Keywords: Noise Detector, Voice Alert, Inpatient, Microcontroller

\section{Pendahuluan}

Sumber kebisingan pada ruang rawat inap rumah sakit salah satunya percakapan antar pengunjung, dokter, perawat maupun pasien rumah sakit itu sendiri. Secara objektif percakapan antar manusia itu wajar, namun bagi pasien yang dalam tahap penyembuhan sangat menggangu bahkan menghambat proses penyembuhan. Gangguan psikologis yang didapat dari kebisingan yaitu dapat berupa rasa tidak nyaman, kurang konsentrasi, dan cepat 
marah.Bila kebisingan diterima dalam waktu lama dapat menyebabkan penyakit psikosomatik berupa gastritis, jantung, stres, kelelahan dan lain-lain.Bising juga dapat berpengaruh terhadap produktifitas kerja bagi dokter maupun perawat.

Mengingat dampak negatif dari pemaparan kebisingan bagi pasien rumah sakit, sebisa mungkin diusahakan agar tingkat kebisingan yang memapari pasien rumah sakit lebih rendah dari baku tingkat kebisingan. Oleh karena itu, organisasi kesehatan dunia WHO (World Health Organization) dan Menteri Kesehatan Republik Indonesia (MenKes RI) menetapkan batas maksimal nilai kebisingan yang diperbolehkan sangat besar untuk skala percakapan manusia.

Percakapan normal manusia berada pada rentang intensitas $30 \mathrm{~dB}-50 \mathrm{~dB}$, namun $40 \mathrm{~dB}$ adalah nilai intensitas maksimal yang diperkenankan di lingkungan rawat inap yang ditetapkan oleh WHO (World Health Organization) dan Keputusan Menteri Kesehatan Republik Indonesia (Kemenkes RI) Tahun 2004 maksimum kebisingan di ruang rawat inap pasien yaitu $45 \mathrm{~dB}$ saat tidak tidur dan $40 \mathrm{~dB}$ saat tidur. Dari hasil penelitian, Kenyataan yang terjadi kebisingan di ruang rawat inap rumah sakit bekisar 77,41 dB - 85,69 DB (Novi Suryanti, Nurhasanah, 2014)

Ini menandakan bahwa kebisingan diruang rawat inap rumah sakit merupakan masalah serius, sesuai fungsinya rumah sakit merupakan tempat untuk merawat orang yang sakit, maka lingkungan rumah sakit sangat membutuhkan suasana yang tenang, nyaman dan terbebas dari kebisingan. Sistem ini diharapkan dapat mengontrol kebisingan dan memberikan kenyamanan bagi pasien rawat inap dari kebisingan demi proses penyembuhan

\section{Tinjauan Literatur}

Tinjaan literature berisi teori dan konsep yang berkaitan erat dengan masalah dalam penelitian, seperti teori mengenai pendeteksian kebisingan, rawat inap, mikrokontroler, ATMega.

\subsection{Pendeteksian Kebisingan}

Pendeteksi merupakan proses, cara, perbuatan mendeteksi; pelacakan. maka Sistem Pendeteksi yaitu suatu alat atau komponen untuk memeriksa, melakukan pemeriksaan, menemukan keberadaan baik itu anggapan atau kenyataan terhadap sesuatu dengan menggunakan cara dan teknik tertentu.

Kebisingan adalah bunyi yang tidak diinginkan dari usaha atau kegiatan dalam tingkat dan waktu tertentu yang dapat menimbulkan gangguan kesehatan manusia dan kenyamanan lingkungan (KepMenLH No. 48, 1996).Kebisingan juga dapat diartikan sebagai bunyi atau suara yang tidak dikehendaki dan dapat mengganggu kesehatan dan kenyamanan lingkungan yang dinyatakan dalam satuan desibel (dB). Kebisingan juga dapat didefinisikan sebagai bunyi yang tidak disukai, suara yang mengganggu atau bunyi yang menjengkelkan\{Formatting Citation\}.

Baku tingkat kebisingan adalah batas maksimal tingkat kebisingan yang diperbolehkan dibuang ke lingkungan dariusaha kegiatan sehingga tidak menimbulkan gangguan kesehatan manusia dan kenyamanan lingkungan. (KepMenLH No 48 :1996). Dapat dilihat pada tabel 1 sebagai berikut:

Tabel 1: Baku Tingkat Kebisingan di lingkungan kegiatan

\begin{tabular}{|c|l|c|}
\hline No & \multicolumn{1}{|c|}{$\begin{array}{c}\text { Lingkungan } \\
\text { Kegiatan }\end{array}$} & $\begin{array}{c}\text { Tingkat Kebisingan } \\
\text { DB(A) }\end{array}$ \\
\hline 1 & Rumah Sakit & 55 \\
\hline 2 & Sekolah & 55 \\
\hline 3 & Tempat Ibadah & 55 \\
\hline
\end{tabular}

Keputusan Menteri Kesehatan RI tentang persyaratan kesehatan lingkungan rumah sakit untuk indeks kebisingan berdasarkan ruang atau unit rumah sakit tercantum pada tabel 2 dibawah ini : 
Tabel 2. Indeks kebisingan berdasarkan Ruangan atau Unit Rumah Sakit

\begin{tabular}{|c|l|c|}
\hline No & Lingkungan Kegiatan & $\begin{array}{c}\text { Tingkat } \\
\text { Kebisingan } \\
\text { DB(A) }\end{array}$ \\
\hline 1 & $\begin{array}{c}\text { Ruang Pasien } \\
\text { Saat tidak } \\
\text { tidur } \\
\text { Saat tidur }\end{array}$ & 45 \\
\hline 2 & Ruang Operasi , umum & 40 \\
\hline 3 & Anestesi, pemulihan & 45 \\
\hline 4 & Endoskopi, & 45 \\
\hline 5 & laboratorium & 65 \\
\hline 6 & Sinar X & 40 \\
\hline 7 & Koridor & 40 \\
\hline 8 & Tangga & 45 \\
\hline 9 & Kantor/loby & 45 \\
\hline 10 & Ruang alat/gudang & 45 \\
\hline 11 & Farmasi & 45 \\
\hline 12 & Dapur & 78 \\
\hline 13 & Ruang cuci & 78 \\
\hline 14 & Ruang isolasi & 40 \\
\hline & Ruang Poli gigi & 80 \\
\hline
\end{tabular}

\subsection{Rawat Inap}

Rawat inap adalah pelayanan terhadap pasien yang masuk ke rumah sakit yang menggunakan tempat tidur untuk keperluan observasi, diagnosis, terapi, rehabilitasi medik dan penunjang medik lainnya (DEPKES RI, 1987).Ruangan rawat inap berupa bangsal yang di huni oleh beberapa pasien sekaligus, namun pada beberapa rumah sakit juga menyediakan kategori kelas untuk ruangan rawat inap. Semakin tinggi kelas tersebut maka ruangan rawat inap akan memiliki fasilitas dan pelayanan yang melebihi standar fasilitas dan pelayanan kelas biasa.

\subsection{Mikrokontroller}

Mikrokontroler merupakan sistem mikroprosesor lengkap yang terkandung di dalam sebuah chip. Mikrokontroler berbeda dari mikroprosesor serba guna yang digunakan dalam sebuah PC, karena di dalam sebuah mikrokontroler umumnya telah terdapat komponen pendukung sistem minimal mikroprosesor, yakni memori dan antarmuka I/O, bahkan ada beberapa jenis mikrokontroler yang memiliki fasilitas ADC, PLL, EEPROM dalam satu kemasan, sedangkan di dalam mikroprosesor umumnya hanya berisi CPU saja.

Secara khusus dapat dikatakan bahwa mikrokontroller merupakan suatu alat elektronika digital yang mempunyai masukan dan keluaran serta kendali dengan program yang bisa ditulis dan dihapus dengan cara khusus. Dalam Hal penggunaannya, sistem mikrokontroller lebih banyak dipakai pada aplikasi yang deterministik, artinya sistem ini dipakai untuk keperluan yang tertentu saja misalkan sebagai pengontrol PID pada instrumentasi industri, pengontrol komunikasi data pada sistem kontrol terdistribusi dan sebagainyaTuwaidan et al., 2015.

\subsubsection{ATMega 8535}

Mikrokontroler ATmega8535 merupakan mikrokontroler 8-bit teknologi CMOS dengan konsumsi daya rendah yang berbasis arsitektur enhanced RISC AVR. Dengan eksekusi instruksi yang sebagian besar hanya menggunakan satu siklus clock, ATMega8535 mencapai throughput sekitar 1 MIPS per MHZ yang mengizinkan perancangan system melakukan optimasi konsumsi daya versus kecepatan pemrosesan(Syahrul, 2012).

Prosessor AVR menggabungkan set intruksi yang kaya dengan 32 register umum (general purpose register, GPRs). Ke semua 32 register tersebut dikoneksi langsung dengan Arithmetic Logic Unit (ALU), mengizinkan dua register independen untuk diakses dalm satu intruksi yang di eksekusi dalam satu siklus clock.Arsitektur yang dihasilkan adalah arsitektus yang kode operasinya lebih efisien serta mencapai throughput nya hinggga sepuluh kali lebih cepat dari pada mikrokontroler CISC (Complex Intruction Set Computer) konvensional.

Pada On-chip ISP Flash mengizinkan memori program untuk diprogram ulang dalam system melalui sebuah antar muka SPI serial, dengan 
menggunakan programmer memori nonvolatile konvensional, atau dengan sebuah On-chip Boot program yang sedang beoperasi pada AVR core. Boot program dapat menggunakan antarmuka maupun untuk mengunduh program aplikasi ke dalam Application Flash memory. Perangkat lunak pada Boot Flash section akan tetap beroperasi ketika application Flash Section di'update',menyediakan operasi ReadWhile-Read yang sebenarnya. Dengan menggabungkan sebuah CPU 8-bit RISC dengan In-System Self-Programmable Flash pada sebuah chip monolithik, ATmel ATmega8535 merupakan mikrokontroler yang tangguh yang menyediaka fleksibilitas tinggi dan solusi biaya sfektif untuk berbagai aplikasi control embedded.Beberapa fitur utama yang tersedia pada ATmeega835 adalah :

1. Port I/O 32 bit, yang dikelompokkan dalam: PortA, PortB, PortC dan PortD

2. Analog to Digital Converter 10-bit sebanyak 8 input

3. Timer/Counter sebanyak 3 buah

4. $C P U 8$ bit yang terdiri dari 32 register

5. Watchdog Timer dengan osilator internal

6. SRAM sebesar 512 byte

7. Memori flash sebesar 8 Kbyte dengan kemapuan Write While Read

8. Interrupt internal maupun eksternal

9. Port komunikasi SPI

10. EEPROM sebesar 512 byte yang terdapat deprogram saat di operasi

11. Analog Comparator

12. Komunikasi serial standar USART dengan kecepatan maksimal 2,5 Mbps

13. Frekuensi clock maksimum 16 $\mathrm{MHz}$

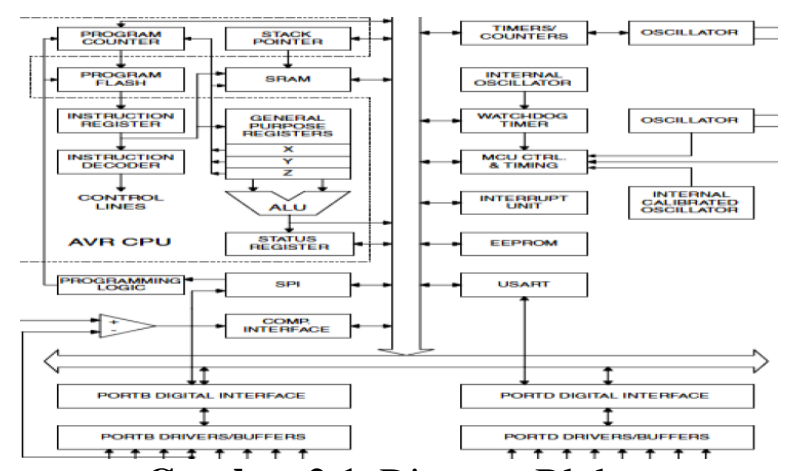

Gambar 2.1. Diagram Blok

Mikrokontroler ATmega8535

Sumber : www.microchip.com

Konfigurasi pin mikrokontroler AVR ATmega8535 untuk 40 pin DIP (Dual In line Package) ditunjukkan pada gambar 2.2 sebagai berikut:

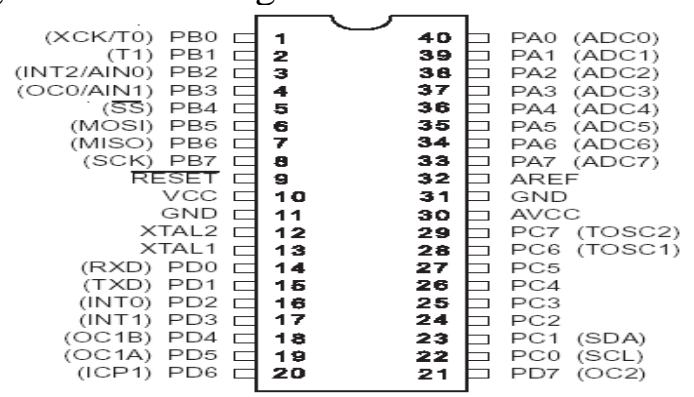

Gambar 2.2. Konfigurasi Pin ATmega8535

Sumber : www.microchip.com

\subsubsection{ISD 2560}

ISD2560 merupakan salah satu chip recorder yang memiliki kualitas bagus untuk melakukan perekaman atau putar ulang selama 60 detik. Perlengkapan CMOS juga termasuk didalamnya, microphone preamplifier, automatic gain control (AGC), antialiasing filter, smoothing filter, dan speaker amplifier (Anonim, 2003).

Dalam hal kualitas suara, ISD2560 memiliki masukan sampling frequency sekitar $8.0 \mathrm{KHz}$. Contoh suara akan disimpan secara langsung ke dalam IC pada bagian nonvolatile memory tanpa proses digitalisasi dan kompresi, sehingga suara yang tersimpan tidak akan hilang jika sumber daya pada IC dilepas. Penyimpanan suara analog secara 
langsung dengan bantuan microphone, sedangkan tiruan dari suara asli, musik, nada, dan efek suara bisa dimasukkan ke dalam IC ini dengan bantuan kabel keluaran audio yang disambungkan dengan salah satu pin dari IC. Selain itu, ISD2560 juga bisa dihubungkan dengan mikrokontroler. Jalur alamat dan jalur kendali bisa dihubungkan dengan input/output pada mikrokontroler dan dapat dimanipulasi untuk menampilkan variasi dari tugas. Termasuk didalamnya kumpulan pesan yang terekam, urutan pesan suara, serta pengelolaan pesan suara yang ada di dalam ISD2560.

Fitur yang dimiliki ISD2560 sebagai berikut :

1. Mudah untuk menggunakan ISD2560 sebagai perekam dan putar ulang.

2. Memiliki kualitas yang bagus pada suara asli ataupun suara tiruan.

3. Saklar manual ataupun mikrokontroler bisa digunakan pada saat putar ulang, yaitu dengan memberikan pulsa aktivasi.

4. Memiliki durasi rekam atau putar ulang selama 60 detik.

5. Jika membutuhkan durasi yang lebih panjang, IC bisa disambungkan secara seri.

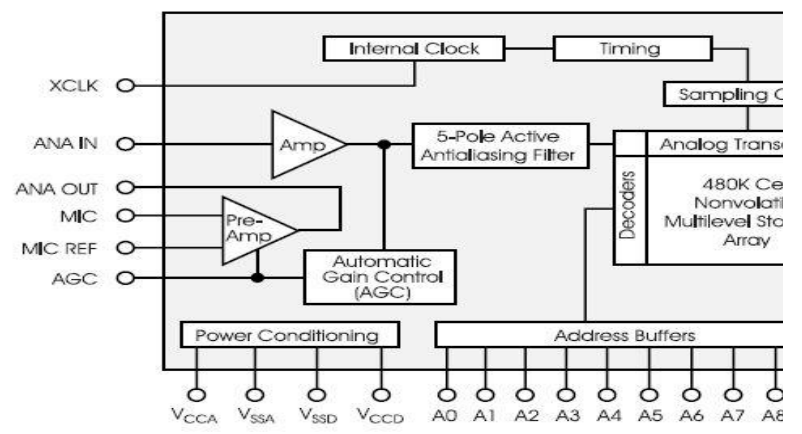

Gambar 2.3. Blok Diagram ISD2560

Sumber : $\mathrm{http}: / / \mathrm{www}$. winbond.com

Untuk konfigurasi pin ISD2560 dapat dilihat pada Gambar 2.4 dibawah ini:

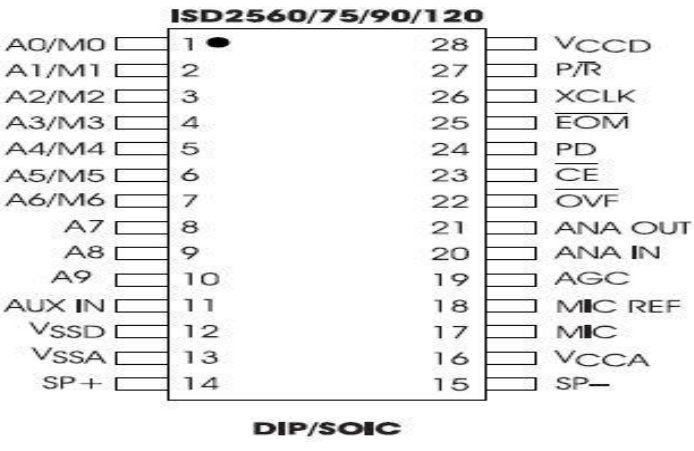

Gambar 2.4. Konfigurasi Pin ISD2560

Sumber : http://www.winbond.com

\subsubsection{Electric Condenser Microphone (ECM)}

Electric Condenser Microphone adalah sensor suara yang sistem listriknya berdasarlan perubahan kapasitansi internalnya.Microphone condenser memerlukan daya dari bateraiatau sumber luar. Microphone memberikan output sinyal analog yang sebanding dengan perubahan tekanan akustik bergantung pada fleksibitas diaphragm. Sinyal listrik kemudiandigunakan untuk pengiriman, perekaman atau pengukuran pada karakteristik sinyalakustik. Salah satu tipe microphone yang biasa digunakan untuk kepentingan musikaladalah tipe condenser.

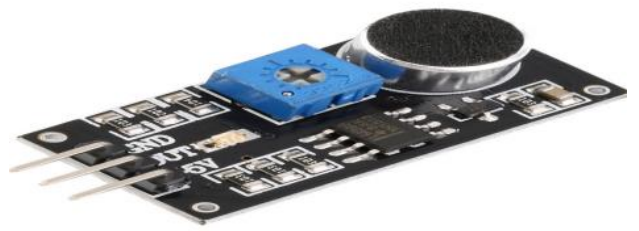

\section{Gambar 2.5.Electric Condenser Microphone}

Sumber :https://www.aliexpress.com

\section{Metodologi Penelitian}

Dalam melakukan sebuah penelitian memerlukan data dan informasi yang bersifat objektif digunakan sebagai titik acuan untuk penelitian, dengan adanya data penelitian yang dihasilkan akan berkualitas. Dalam pembahasan metode penelitian ini, maka dapat dituangkan tahapan penelitian atau rangkaian kegiatan ke kerangka kerja penelitian. 


\subsection{Kerangka Kerja Penelitian}

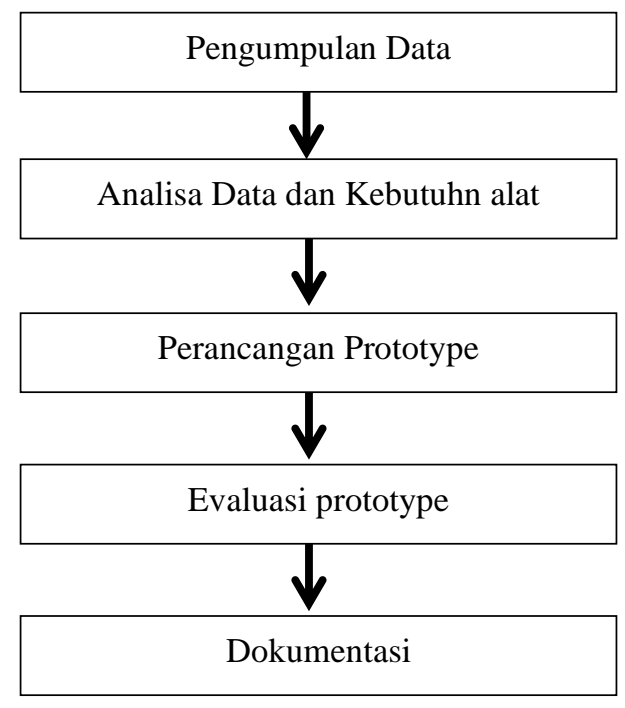

Gambar 2.1Kerangka kerja Penelitian

Uraian diagram rangkaian metode penelitian sebagai berikut:

1. Pengumpulan Data, melalui tinjauan pustaka dari jurnal dan buku, wawancara dan survei langsung ke Rumah Sakit Umum Daerah (RSUD) Arifin Achmad Pekanbaru.

2. Analisa Data dan Kebutuhan Alat, tahap ini diperlukan untuk merancang sistem yang dibuat.

3. Perancangan prototype, setelah data dan alat tersedia dilanjutkan mendesain sistem dan melakukan coding dengan tool yang tersedia.

4. Evaluasi Prototype, evaluasi ini untuk mengetahui kinerja sistem ini terjadinya kesalahan untuk dilakukan penyempurnaan sistem.

5. Dokumentasi, tahap ini dilakukan setelah dilakukan ujicoba dan evaluasi untuk memudahkan pengguna dalam menjalankan sistem ini.

\section{Hasil dan Diskusi}

Hasil dari penerapan dalam sistem meliputi hardware, software, implementasi, pengujian dan evaluasi pengujian sebagai berikut:

\subsection{Hardware}

Spesifikasi hardwareyang digunakan sebagai berikut :

1. Sistem Minimum Atmega8535, berfungsi sebagai kontrol utama sistem

2. Sensor Suara ECM (Electric Condenser Microphone), berfungsi untuk medeteksi level kebisingan

3. ICISD 2560 (Informations Storage Device)

4. LCD $16 \times 2$, berfungsi sebagai display pengukuran kebisingan

5. SwitchButton, berfungsi sebagai input counter up dan counter down batas maksimal kebisingan

6. Speaker, berfungsi sebagai penghasil suara dari output isd 2560

7. Power Supply, sebagai catudaya tegangan keseluruhan sistem

8. Laptop Acer Aspire 4738z, Intel Pentium 2.00 Ghz :Ram 2GB.

Alat pendukung perancangan alat sebagai berikut :

1. Solder

2. Timah solder

3. Tang potong

4. Obeng

5. Kabel jumper

6. SLM (Sound Level Meter)

\subsection{Software}

Spesifikasi software yang digunakan sebagai berikut :

1. Sistem operasi windows 7 ultimate 32-bit

2. Bascom-AVR 2.0.7.5, untuk mengetik scrip program dan menkonversi menjadi data .hax 
3. Prog isp Ver 1.72, untuk mengupload program ke mikrokontroller

4. Downloader, sebagai penghubung prog isp ke mikrokontroller

\subsection{Implementasi}

Implementasi Prototype gambaran dari ruang rawat inap rumah sakit yang dibuat menggunakan Acrilix.Digambarkan, alat di letakkan di ruang administrasi, untuk sensor suara di letakkan di dalam kamar rawat inap.

Untuk rangkaian keseluruhan alat dapat dilihat pada gambar 4.1 dibawah ini :

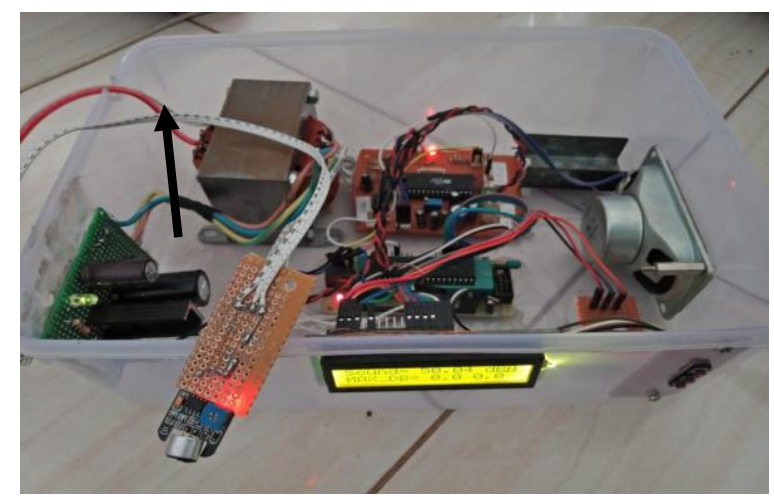

Gambar 4.1. Hasil rangkaian keseluruhan

\subsection{Pengujian}

Metode pengujian yang digunakan dalam penelitian adalah black box testing.Pengujian black box berfokus pada persyaratan fungsional sistem. Dengan demikian pengujian black box memungkinkan perekayasa sistem mendapatkan serangkaian kondisi input yang sepenuhnya menggunakan semua persyaratan fungsional untuk semua program. Kebenaran sistem yang diuji hanya dilihat berdasarkan keluaran yang dihasilkan dari data atau kondisi masukkan yang diberikan untuk fungsi yang ada tanpa melihat bagaimnana proses untuk mendapatkan keluaran tersebut. Dari keluaran yang dihasilkan kemampuan program dalam memenuhi kebutuhan pemakai dapat diukur sekaligus dapat diketahui kesalahan - kesalahannya.

Uji coba dengan Black Box pada sistem ini bertujuan untuk menentukan fungsi cara beroprasinya, apakah pemasukan data keluaran telah berjalan sebagaimana yang diharapkan. Berikut dibawah ini hasil pengujian keseluruhan alat yang tercantum di tabel4.1

Tabel 4.1.Pengujian Rangkaian Keseluruhan

\begin{tabular}{|c|c|c|c|}
\hline $\begin{array}{c}\text { Penguji } \\
\text { an }\end{array}$ & Aksi & Keterangan & Gambar \\
\hline $\begin{array}{l}\text { Pengujia } \\
n \text { LCD }\end{array}$ & $\begin{array}{l}\text { Pengujian lcd } \\
\text { dilakukan } \\
\text { dengan } \\
\text { memasukkan } \\
\text { program text lcd } \\
\text { pada } \\
\text { atmega8535 }\end{array}$ & $\begin{array}{l}\text { Lcd dapat } \\
\text { menampilkan data } \\
\text { berupa karakter } \\
\text { dari atmega8535 }\end{array}$ & \\
\hline $\begin{array}{l}\text { Pengujia } \\
\text { n Sensor }\end{array}$ & $\begin{array}{l}\text { Pengujian } \\
\text { sensor } \\
\text { dilakukan } \\
\text { dengan } \\
\text { memberi suara } \\
\text { kebisingan pada } \\
\text { sensor dan } \\
\text { memasukkan } \\
\text { program pada } \\
\text { atmega8535 } \\
\text { untuk data } \\
\text { sensor } \\
\text { ditampilkan di } \\
\text { lcd } \\
\end{array}$ & $\begin{array}{l}\text { Sensor dapat } \\
\text { men\&pekaker } \\
\text { k ebisingan dan } \\
\text { nilai kebisingan } \\
\text { ditam ilkan di lcd }\end{array}$ & \\
\hline $\begin{array}{l}\text { Pengujia } \\
\mathrm{n} \text { Switch } \\
\text { Button }\end{array}$ & $\begin{array}{l}\text { Pengujian } \\
\text { Switch Button } \\
\text { dilakukan } \\
\text { dengan } \\
\text { menekan } \\
\text { tombol } \\
\text { switchup, } \\
\text { Switch down } \\
\text { dan Switch ok. }\end{array}$ & $\begin{array}{ll}\text { - } & \text { Switch up }= \\
\text { menaikkan } & \\
\text { batas max } & \text { kebisingan } \\
\text { - } & \text { Switch down } \\
= & \\
\text { menurunkan } \\
\text { batas max } \\
\text { kebisingan } \\
\text { - Switch ok= } \\
\text { mengaktifkan } \\
\text { bajas max } \\
\text { ket singan }\end{array}$ & \\
\hline $\begin{array}{l}\text { Pengujia } \\
\mathrm{n} \\
\text { rangkaia } \\
\mathrm{n} \\
\text { ISD2560 }\end{array}$ & $\begin{array}{l}\text { Pengujian } \\
\text { isd2560 } \\
\text { dilakukan } \\
\text { dengan } \\
\text { merekam suara } \\
\text { dan memutar } \\
\text { ulang hasil } \\
\text { rekaman }\end{array}$ & $\begin{array}{l}\text { sd256fch dapat } \\
\text { merekam suara } \\
\text { dari microphone } \\
\text { dan menyimpan } \\
\text { hasil rekaman } \\
\text { serta memutar } \\
\text { ulang hasil } \\
\text { rekaman di } \\
\text { speaker. Pada } \\
\text { gambar ditandai } \\
\text { dengan hidupnya } \\
\text { lampu led }\end{array}$ & \\
\hline
\end{tabular}

Dari tabel 4.1pengujian keseluruhan alat diatas diketahui bahwa setiap komponen rangkaian dapat bekerja sesuai dengan aksi dan hasil nya masing-masing.

\subsection{Evaluasi Pengujian}


Berikut dibawah ini tabel 4.2Evaluasi pengujian untuk melihat status pengujian yang dilakukan:

Tabel 4.2. Evaluasi pengujian

\begin{tabular}{|c|l|c|c|}
\hline \multirow{2}{*}{ No } & \multicolumn{1}{|c|}{ Jenis Pengujian } & \multicolumn{2}{|c|}{ Status Pengujian } \\
\cline { 3 - 4 } 1 & $\begin{array}{l}\text { Sensor suara mendeteksi } \\
\text { kebisingan }\end{array}$ & $\checkmark$ & \\
\hline 2 & $\begin{array}{l}\text { Pada Lcd menampilkan nilai } \\
\text { tingkat kebisingan }\end{array}$ & $\checkmark$ & \\
\hline 3 & $\begin{array}{l}\text { ISD2560 menyimpan hasil } \\
\text { rekaman dan memutar ulang } \\
\text { rekaman }\end{array}$ & $\checkmark$ & \\
\hline 4 & $\begin{array}{l}\text { Switch Button bisa menaikan } \\
\text { dan menurunkan batas } \\
\text { maksimal kebisingan }\end{array}$ & $\checkmark$ & \\
\hline 5 & $\begin{array}{l}\text { Speaker aktif ketika kebisingan } \\
\text { diatas batas maksimal } \\
\text { kebisingan }\end{array}$ & $\checkmark$ & \\
\hline
\end{tabular}

Pada tabel 4.3, alat bekerja sesuai dengan sistem yang dibangun yaitu berhasil menampilkan tingkat kebisingan dan mengeluarkan pesan peringatan suara ketika kebisingan diatas batas maksimal kebisingan.

\section{Kesimpulan}

Dari hasil pembuatan dan pengujian sistem yang telah dilaksanakan maka dapat ditarik kesimpulan sebagai berikut:

1. Hasil pengujian dari alat dengan menggunakan mikrokontroller atmega8535 dengan sensor suara electric condenser sensor sebagai pendeteksi kebisingan berjalan dengan baik. Penggunaan ISD2560 sebagai penyimpan rekaman suara peringatan dan speaker sebagai pengeras suara.

2. Alat yang dibangun dapat mendeteksi kebisingan dan menampilkan tingkat kebisingan di lcd dalam satuan decibel $(\mathrm{dB})$

3. Pesan suara yang di keluarkan dari output speaker berdasarkan batas nilai maksimal tingkat kebisingan.

4. Jarak sensor dalam mendeteksi kebisingan terbatas.

\section{Referensi}

[1] Gani, L. R., \& dkk. (2018). Hubungan antara Kebisingan di Tempat Kerja dengan Kualitas Tidur pada Pekerja Pabrik Kayu PT. Muroco Jember The Correlation between Noise in Workplace and Sleep Quality in Workers at PT. Muroco Jember Wood Processing Factory. Agromedicine and Medical Sciences, 4(2), 1-5.

[2] Novi Suryanti, Nurhasanah, A. I. (2014). TINGKAT KEBISINGAN AKIBAT AKTIVITAS MANUSIA DI RUANG INAP RUMAH SAKIT. PRISMA FISIKA, II(2), 49-54.

[3] Tuwaidan, Y. A., Poekoel, E. V. C., Mamahit, D. J., \& Eng, M. (2015). Rancang Bangun Alat Ukur Desibel ( dB ) Meter Berbasis Mikrokontroler Arduino Uno R3. E-Jurnal Teknik Elektro Dan Komputer, 1(1), 37-43. 